\title{
EFFECTS OF CHUANXIONG RHIZOMA-CYPERI RHIZOMA COMBINATION ON MIGRAINE IN A MURINE MODEL
}

\author{
PING NIU ${ }^{1}$, TIANYE LAN ${ }^{1}$, JINJIAN LI $^{1}$, YUE WANG ${ }^{1 *}$ \\ ${ }^{1}$ Department of Neurology, The Affiliated Hospital to Changchun University of Chinese Medicine, Changchun, 130021, Jilin, China
}

*corresponding author: wangyueahe592@126.com

Manuscript received: November 2020

\begin{abstract}
Chuanxiong Rhizoma-Cyperi Rhizoma combination is a traditional anti-migraine treatment used for years in Traditional Chinese Medicine. This study aimed to evaluate the efficacy and the underlying mechanism of using this combination in a murine model of migraine. Forty-eight male Wistar rats were randomly divided into 6 groups, a normal group, a migraine model group, a Flunarizine group used as a positive therapeutic effect group and high, medium, and low dose Chuanxiong Rhizoma-Cyperi Rhizoma combination groups. Seven days before migraine induction, the animals from the Flunarizine group received $0.43 \mathrm{mg} / \mathrm{kg}$ bw/day flunarizine, the animals from Chuanxiong Rhizoma-Cyperi Rhizoma combination groups received 6,3 and $1.5 \mathrm{~g} / \mathrm{kg}$ bw/day of alcoholic extract powder, while the normal group and the model group received the same amount of saline solution. After the model induction, the behavioural signs of migraine, calcitonin gene-related peptide (CGRP), interleukin-1 $\beta$ (IL-1 $\beta$ ), tumour necrosis factor- $\alpha$ (TNF- $\alpha$ ) levels both in serum and brain tissue, nitric oxide (NO) levels, nitric oxide synthase (NOS) activity and nitric oxide/endothelin (NO/ET) ratio in serum significantly increased compared with the normal group, while the levels of 5-hydroxytryptamine (5-HT), $\beta$-Endorphin ( $\beta$-EP) both in serum and brain tissue and ET in serum significantly decreased. The pre-treatment with Flunarizine and increasing doses of Chuanxiong Rhizoma-Cyperi Rhizoma combination groups significantly reversed. The effect on increasing the 5-HT levels and decreasing IL-1 $\beta$, TNF- $\alpha$ n, NOS and NO levels was superior for the high dose group compared with the Flunarizine group. In conclusion, Chuanxiong Rhizoma-Cyperi Rhizoma combination showed beneficial effects in a migraine murine model by modulating the neurogenic inflammation and the levels of neurotransmitter and vasomotor factors.
\end{abstract}

\section{Rezumat}

Combinația Chuanxiong Rhizoma-Cyperi Rhizoma este un tratament anti-migrenos folosit în medicina tradițională chineză. Acest studiu a avut ca scop evaluarea eficacității și a mecanismului ce stă la baza utilizării acestei combinații într-un model murin de migrenă. Patruzeci și opt de șobolani masculi Wistar au fost împărțiți în mod aleatoriu în 6 grupuri: un grup de control, un grup model de migrenă, un grup Flunarizină utilizat ca martor pozitiv și 3 grupuri cărora li s-a administrat combinația Chuanxiong Rhizoma-Cyperi Rhizoma în doză mare, medie și mică. Cu șapte zile înainte de debut, animalele din grupul Flunarizină au primit $0,43 \mathrm{mg} / \mathrm{kg}$ corp/zi flunarizină, animalele din grupurile cărora li s-a administrat combinația Chuanxiong Rhizoma-Cyperi Rhizoma au primit 6,3 și 1,5 g/kg corp/zi de extract alcoolic, în timp ce grupul normal și grupul model au primit aceeași cantitate de soluție salină. După inducerea migrenei au fost evaluate semnele de comportament specifice și nivelurile peptidei asociate genei calcitoninei (CGRP), interleukinei-1 $\beta$ (IL-1 $\beta$ ), factorului de necroză tumorală- $\alpha$ (TNF- $\alpha$ ), în ser și în țesutul cerebral. Nivelurile oxidului nitric (NO), activitatea nitric oxid sintazei (NOS) și raportul oxid nitric/endotelină în ser au crescut semnificativ în comparație cu grupul normal, în timp ce nivelurile de 5-hidroxitriptamină (5-HT), $\beta$-endorfină ( $\beta$-EP ) atât în ser, cât și țesutul cerebral, au scăzut semnificativ. Aceste efecte au fost contracarate de pre-tratamentul cu Flunarizină și dozele crescute ale combinației Chuanxiong Rhizoma-Cyperi Rhizoma. Efectele au fost superioare pentru grupul tratat cu doză mare de Chuanxiong Rhizoma-Cyperi Rhizoma comparativ cu grupul Flunarizină. În concluzie, combinația Rhizoma Cyuanxiong-Cyperi Rhizoma a demonstrat efecte benefice într-un model murin de migrenă prin modularea inflamației neurogene și a nivelurilor neurotransmițătorilor și a factorilor vasomotori.

Keywords: Chuanxiong rhizome, Cyperi rhizome, migraine, neurotransmitter, neurogenic inflammation

\section{Introduction}

Migraine is a common clinical disease characterized by repeated episodes of unilateral or bilateral pulsating headaches, accompanied by symptoms such as nausea, vomiting, and photophobia [1]. The specific pathogenesis is complex and changeable. In traditional Chinese medicine, Chuanxiong Rhizoma (dry rhizomes of Ligusticum chuanxiong Hort, Umbelliferae and Cyperi Rhizoma (dry rhizomes of
Cyperus rotundus L., Cyperaceae are the most commonly used plants for pain treatment. Chuanxiong Rhizoma is known to improve blood circulation, removing blood stasis, promoting qi and relieving pain [2]. Cyperi Rhizoma can regulate qi, relieve depression, regulate menstruation and relieve pain [3]. The use of Chuanxiong Rhizoma-Cyperi Rhizoma combination is first stated in Danxi Xinfa (a comprehensive medical book written by Zhu 
FARMACIA, 2021, Vol. 69, 4

Zhenheng in 1481) for the alleviation of headache with a syndrome of phlegm syncope and migraine headache [4]. Pharmacological studies have shown that the combination of Chuanxiong Rhizoma and Cyperi Rhizoma can reduce the number of writhing times in dysmenorrhea rat model to varying degrees, can prolong the writhing latency and can reduce the whole blood viscosity of rats [5]. Besides, it can also treat migraines caused by vegetative nerve functional and vasomotor disorders [6]. Ferulic acid (FA) is the main component of Chuanxiong Rhizoma and was associated with properties for promoting qi and relieving pain. Studies reported that FA has certain effects on promoting angiogenesis, decreasing blood pressure, alleviating cerebral ischemia, ischemic myocardial reperfusion injury and vasospasm [7, 8]. In this study, we aimed to evaluate the effects of the combination of Chuanxiong Rhizoma and Cyperi Rhizoma on alleviating migraine symptoms using a nitroglycerin migraine murine model.

\section{Materials and Methods}

\section{Animals}

Forty-eight healthy male Wistar rats, weighing 190 - 210g, were provided by Beijing Weitong Lihua Laboratory Animal Technology Co., Ltd., China. All rats were housed under a 12-hour light and dark cycle and were given free access to food and water. The temperature and humidity of the animal facility were controlled at $22 \pm 2^{\circ} \mathrm{C}$ and $40-60 \%$, respectively. The rats were allowed for 1-week acclimation before the experiment. The protocol was approved by the ethics committee of The Affiliated Hospital to the Changchun University of Chinese Medicine, and the experiment was carried out following the regulations of the State Science and Technology Commission on the management of laboratory animals.

\section{Materials}

The materials used in the experiment were: Chuanxiong Decoction Pieces (Jiangyin Yaojiang Pharmaceutical Co., Ltd.,China), Cyperi Rhizoma Decoction Pieces (Jiangyin Yaojiang Pharmaceutical Co., Ltd., China); Nitroglycerin $(5 \mathrm{mg} / \mathrm{mL}$, Henan Runhong Pharmaceutical Co., Ltd., China); Flunarizine Hydrochloride Capsules (Sibelin ${ }^{\circledR}$ ) (Xian Janssen Pharmaceutical Ltd., $5 \mathrm{mg} /$ capsule).

Preparation of alcohol extracts from Chuanxiong Rhizoma-Cyperi Rhizoma

For the preparation of alcoholic extract, $50 \mathrm{~g}$ dry rhizomes of Ligusticum chuanxiong Hort (Chuanxiong Rhizoma) and $100 \mathrm{~g}$ dry rhizomes of Cyperus rotundus L. (Cyperi Rhizoma) were mixed in a round bottom flask with $1000 \mathrm{~mL}$ 75\% ethanol solution and underwent reflux extraction twice for $2 \mathrm{~h}$ each time. The extracted liquid was concentrated till the final concentration of $1 \mathrm{~kg}$ alcoholic extract/L. The solution was filtered to remove the sediment. The filtrate was concentrated under reduced pressure. The obtained liquid was further concentrated to a thick paste in a water bath at $85^{\circ} \mathrm{C}$ and then underwent vacuum drying till $20.55 \mathrm{~g}$ of powder was obtained.

Establishment of nitroglycerin migraine animal model Forty-eight male Wistar rats were acclimatized to the new laboratory conditions for one week before the experiment. After acclimatization, according to their weight, they were randomly divided into the normal group, model group, Flunarizine group (0.43 $\mathrm{mg} / \mathrm{kg}$ bw/day), high, medium, and low dose groups of Chuanxiong Rhizoma-Cyperi Rhizoma combination, 8 rats in each group. Flunarizine group was used as a positive control for anti-migraine effects and the animals received daily for seven days before migraine induction $0.43 \mathrm{mg} / \mathrm{kg}$ bw/day flunarizine hydrochloride dissolved in saline solution in a volume of $10 \mathrm{~mL} / \mathrm{kg}$ bw intragastrically. The high, medium and low dose groups of Chuanxiong RhizomaCyperi Rhizoma combination received daily for seven days before migraine induction 6.0, 3.0, 1.5 (g/kg bw/day) powder of the alcoholic extract of Chuanxiong Rhizoma-Cyperi Rhizoma dissolved in saline solution in a volume of $10 \mathrm{~mL} / \mathrm{kg}$ bw by gavage. The animals from the model group and the normal group received an equal volume of saline solution every day for 7 days before migraine induction intragastrically. On the $7^{\text {th }}$ day, 30 minutes after the last administration of the treatment, $10 \mathrm{mg} / \mathrm{kg}$ bw of nitroglycerin was subcutaneously injected into the frontal area to the model group and treatment group, while the control group received saline solution. After migraine induction, the rats' ears became red, there were observed frequent head-scratching of forelimbs, increased frequency of climbing cages, irritability and other phenomena, which lasted for some time, and then appeared curled up and reduced activities, indicating that the migraine induction was successful. Behavioural observation

From the time of migraine induction, the animal room monitoring system was used to continuously record the behaviour of each rat within 3 hours after the injection of nitroglycerin (including red ears, head-scratching, head shaking, climbing cage, erect ears, erect hair, skin cyanosis, etc.). The observation time was divided into 30 minutes periods. The appearance time of red ears in each group of animals and the number of animals scratching their heads during the observation period were observed. The start time of head-scratching was marked by the number of head-scratching $>5$ times, and the disappearance time was marked by the number of head-scratching $<5$ times and the appearance of fatigue. The rat's head-scratching behaviour was recorded when the rat was scratching the head with the forelimbs, and the rat's forelimb grasping the 
lid of the cage was used as the recording marker for the cage climbing behaviour.

\section{Biochemical determinations}

Two hours after migraine induction, rats were anaesthetized with an intraperitoneal injection of $10 \%$ chloral hydrate (SenBeiJia Biological Technology Co., Ltd., China) in a dose of $40 \mathrm{mg} / \mathrm{kg}$ bw and then sacrificed by decapitation. Then, $5 \mathrm{~mL}$ of blood was collected from the abdominal aorta, and the serum was separated to determine the levels of endothelin (ET), nitric oxide (NO), nitric oxide synthase (NOS), 5-hydroxytryptamine (5-HT), calcitonin gene-related peptide (CGRP), $\beta$-Endorphin ( $\beta$-EP), interleukin-1 $\beta$ (IL-1 $\beta$ ), and tumour necrosis factor- $\alpha$ (TNF- $\alpha$ ) in the serum. The brain was collected and the midbrain was used to obtain a tissue homogenate. The tissue homogenate was centrifuged at $4^{\circ} \mathrm{C}$ at $4000 \mathrm{rpm}$ for 20 minutes and the supernatant was collected and used to detect the levels of 5-HT, CGRP, $\beta$-EP, IL- $1 \beta$ and TNF- $\alpha$. For ET determination it was used the enzyme-linked immunosorbent assay (ELISA) kit from China Biolink Biotechnology Co., Ltd., China, for NO and NOS determination there were used the ELISA NO assay kit and total nitric oxide synthase assay kit based on nitrate reductase method from Nanjing Jiancheng bioengineering Institute, China and for the other parameters there were used the ELISA kits from eBioscience, USA. All the assays were performed according to the manufacturer instructions.

Statistical analysis

Statistical analysis was performed by SPSS 20.0 (IBM, USA) software. All measurement data were tested for normality first and then tested for homogeneity of variance. If the variance was uniform, it was represented by the mean \pm standard deviation. Onefactor analysis of variance (ANOVA) was used for comparison between multiple groups, and the least significant difference (LSD) method was used for pairwise comparison between groups. If the variance was uneven, the Mann-Whitney U method was used for pairwise comparison. A value of $p<0.05$ indicated that the difference was statistically significant.

\section{Results and Discussion}

Effects of alcoholic extract of Chuanxiong RhizomaCyperi Rhizoma combination on animal behaviour Rats in the model group presented red ears, frequent upper limb scratching, irritability, an increased number of cage climbing at about 3 minutes after migraine induction. After 1 to 3 hours, symptoms such as fatigue and decreased activity appeared. In the normal group, the animals did not present red ears and only occasional head-scratching and cage climbing. There was no statistically significant difference in the appearance time of red ear for the animals ( $\mathrm{p}=$ 0.831).

The number of head-scratching in each time period analysed in the model group was significantly increased compared with the normal group. In the positive control group (Flunarizine group) it was observed a significant reduction in the number of scratching heads in the 61 - 90 minutes, 91 - 120 minutes, and 121 - 150 minutes periods compared with the model group $(\mathrm{p}<0.05)$. The number of head-scratching in the three groups of Chuanxiong Rhizoma-Cyperi Rhizoma combination at each time period was significantly reduced compared with the model group ( $\mathrm{p}<0.05$ ), and the effect was dosedependent. The treatment with the Chuanxiong Rhizoma-Cyperi Rhizoma combination significantly decreased the frequency of scratching head compared with the Flunarizine group in a dose-dependent manner $\mathrm{p}<0.05)$ (Table I).

Table I

Comparison of the occurrence time of red ears and the number of head scratches in different time-periods

\begin{tabular}{|c|c|c|c|c|c|c|c|}
\hline \multirow{2}{*}{ Groups } & \multirow{2}{*}{$\begin{array}{c}\text { Red ears } \\
\text { appearance } \\
\text { time }(\mathrm{min})\end{array}$} & \multicolumn{6}{|c|}{ Number of head scratches in different periods } \\
\hline & & 0 30min & $31 \sim 60 \mathrm{~min}$ & $61 \sim 90 \mathrm{~min}$ & 91 120 min & $121 \sim 150 \mathrm{~min}$ & $151 \sim 180 \mathrm{~min}$ \\
\hline $\begin{array}{c}\text { The normal } \\
\text { group }\end{array}$ & - & $2.01 \pm 0.81$ & $1.34 \pm 0.65$ & $1.42 \pm 0.44$ & $2.08 \pm 0.65$ & $1.41 \pm 0.48$ & $1.43 \pm 0.37$ \\
\hline $\begin{array}{l}\text { The model } \\
\text { group }\end{array}$ & $4.32 \pm 0.21$ & $\begin{array}{c}73.56 \pm 5.53 \\
* *\end{array}$ & $\begin{array}{c}61.51 \pm 6.17 \\
* *\end{array}$ & $\begin{array}{c}56.44 \pm 7.09 \\
* *\end{array}$ & $\begin{array}{c}43.53 \pm 5.53 \\
* *\end{array}$ & $\begin{array}{c}31.36 \pm 4.47 \\
* *\end{array}$ & $\begin{array}{c}15.27 \pm 2.38 \\
* *\end{array}$ \\
\hline $\begin{array}{c}\text { The } \\
\text { Flunarizine } \\
\text { group }\end{array}$ & $3.81 \pm 0.38$ & $\begin{array}{c}68.13 \pm 6.35 \\
* *\end{array}$ & $\begin{array}{c}60.15 \pm 5.32 \\
* *\end{array}$ & $\begin{array}{c}36.06 \pm 5.57 \\
* * \# \#\end{array}$ & $\begin{array}{c}30.27 \pm 5.89 \\
* * \#\end{array}$ & $\underset{* * \#}{26.71 \pm 1.96}$ & $\begin{array}{c}16.35 \pm 2.42 \\
* *\end{array}$ \\
\hline $\begin{array}{c}\text { The low } \\
\text { dose group }\end{array}$ & $4.04 \pm 0.57$ & $\begin{array}{c}30.31 \pm 4.63 \\
\text { **\#\#@@ }\end{array}$ & $\begin{array}{c}21.54 \pm 4.46 \\
\text { **\#\#@@ }\end{array}$ & $\begin{array}{c}19.25 \pm 4.38 \\
\text { **\#\#@@ }\end{array}$ & $\begin{array}{c}13.45 \pm 3.24 \\
* * \# \text { @ @ }\end{array}$ & $\begin{array}{c}5.65 \pm 0.58 \\
* * \# \# @ @\end{array}$ & $\begin{array}{c}2.33 \pm 0.34 \\
\text { **\#\#@@ }\end{array}$ \\
\hline $\begin{array}{c}\text { The } \\
\text { medium } \\
\text { dose group }\end{array}$ & $3.92 \pm 0.43$ & $\begin{array}{c}24.42 \pm 4.14 \\
* * \# \& @ @\end{array}$ & $\begin{array}{c}21.09 \pm 3.28 \\
* * \# @ @ ~\end{array}$ & $\begin{array}{c}18.16 \pm 2.17 \\
\text { **\#\#@@ }\end{array}$ & $\begin{array}{c}10.42 \pm 1.38 \\
\text { **\#\#@@ }\end{array}$ & $\begin{array}{c}4.29 \pm 0.87 \\
\text { *\#\#@@ }\end{array}$ & $\begin{array}{c}1.88 \pm 0.35 \\
\text { *\#\#@@ }\end{array}$ \\
\hline $\begin{array}{l}\text { The high } \\
\text { dose group }\end{array}$ & $3.78 \pm 0.65$ & $\begin{array}{c}22.13 \pm 3.54 \\
* * \# \& \& @ @\end{array}$ & $\begin{array}{c}20.54 \pm 4.40 \\
\text { **\#\#@@ }\end{array}$ & $\begin{array}{c}17.65 \pm 3.21 \\
\text { **\#\#@@ }\end{array}$ & $\begin{array}{c}7.08 \pm 1.07 \\
* \# \# \& @ @\end{array}$ & $\begin{array}{c}3.26 \pm 0.65 \\
* \# \# @ @\end{array}$ & $\begin{array}{c}1.43 \pm 0.46 \\
\text { \#\#@@ }\end{array}$ \\
\hline
\end{tabular}

Note:**p < 0.01 compared with the normal group; ${ }^{\#} \mathrm{p}<0.05,{ }^{\# \#} \mathrm{p}<0.01$ compared with the model group; ${ }^{\&} \mathrm{p}<0.05,{ }^{\& \&} \mathrm{p}<0.01$ compared with low dose group; ${ }^{@} \mathrm{p}<0.05,{ }^{@} @ \mathrm{p}<0.01$ compared with Flunarizine group 
The evaluation of cage-climbing behaviour showed that in the normal group this behaviour was absent, while it appeared in the other groups.

Compared with the model group, rats in the Chuanxiong Rhizoma-Cyperi Rhizoma combination medium-dose group had fewer cage climbing times within the $31-60$ min and $61-90$ min periods. In the Chuanxiong Rhizoma-Cyperi Rhizoma combination high-dose group and the Flunarizine group, the number of cage climbing decreased in the 3 periods of 31 - 60min, 61 - 90min, $91-120 \mathrm{~min}$ ( $\mathrm{p}<0.05$ or $\mathrm{p}<0.01)$ (Table II)

Table II

Comparison of cage-climbing times of each group in different time periods

\begin{tabular}{|c|c|c|c|c|c|c|}
\hline \multirow{2}{*}{ Groups } & \multicolumn{6}{|c|}{ Cage-climbing times at different periods } \\
\hline & 0 30min & 31 60min & $61 \sim 90 \mathrm{~min}$ & $91 \sim 120 \mathrm{~min}$ & $121 \sim 150 \mathrm{~min}$ & 151 180 min \\
\hline The normal group & 0 & 0 & 0 & 0 & 0 & 0 \\
\hline The model group & $\begin{array}{c}18.46 \pm 3.16 \\
* *\end{array}$ & $\begin{array}{c}23.27 \pm 3.56 \\
* *\end{array}$ & $\begin{array}{c}28.98 \pm 4.72 \\
* *\end{array}$ & $17.75 \pm 2.73 * *$ & $\begin{array}{c}14.72 \pm 1.25 \\
* *\end{array}$ & $\begin{array}{c}10.93 \pm 0.43 \\
* *\end{array}$ \\
\hline $\begin{array}{l}\text { The Flunarizine } \\
\text { group }\end{array}$ & $\begin{array}{c}18.47 \pm 3.82 \\
* *\end{array}$ & $\begin{array}{c}13.39 \pm 1.95 \\
* * \# \#\end{array}$ & $\underset{* * \# \#}{15.47 \pm 2.54}$ & $9.48 \pm 1.29 * * \#$ & $\begin{array}{c}8.91 \pm 1.37 \\
* *\end{array}$ & $\begin{array}{c}5.67 \pm 0.48 \\
* *\end{array}$ \\
\hline $\begin{array}{l}\text { The low dose } \\
\text { group }\end{array}$ & $\begin{array}{c}16.87 \pm 3.25 \\
* *\end{array}$ & $\begin{array}{c}21.61 \pm 3.81 \\
* * @\end{array}$ & $\begin{array}{c}26.15 \pm 3.91 \\
* * @\end{array}$ & $\begin{array}{c}16.17 \pm 2.35 \\
* * @\end{array}$ & $\begin{array}{c}12.36 \pm 1.58 \\
* *\end{array}$ & $\begin{array}{c}6.44 \pm 0.58 \\
* *\end{array}$ \\
\hline $\begin{array}{l}\text { The medium dose } \\
\text { group }\end{array}$ & $\begin{array}{c}18.47 \pm 3.14 \\
* *\end{array}$ & $\begin{array}{c}16.27 \pm 2.82 \\
* * \# \&\end{array}$ & $\begin{array}{c}20.37 \pm 3.04 \\
* * \# \& @\end{array}$ & $\begin{array}{c}14.76 \pm 1.73 \\
* * @\end{array}$ & $\begin{array}{c}11.07 \pm 1.36 \\
* *\end{array}$ & $\begin{array}{c}5.76 \pm 0.66 \\
* *\end{array}$ \\
\hline $\begin{array}{l}\text { The high dose } \\
\text { group }\end{array}$ & $\begin{array}{c}17.41 \pm 2.30 \\
* *\end{array}$ & $\begin{array}{c}14.45 \pm 2.10 \\
* * \# \# \mathbb{E}\end{array}$ & $\begin{array}{c}16.47 \pm 2.43 \\
\text { **\#\#\&\& }\end{array}$ & $\begin{array}{c}10.05 \pm 1.66 \\
* * \# \&\end{array}$ & $\begin{array}{c}9.18 \pm 1.56 \\
* * \&\end{array}$ & $\begin{array}{c}5.08 \pm 0.45 \\
* *\end{array}$ \\
\hline
\end{tabular}

Note: ${ }^{* *} \mathrm{p}<0.01$ compared with the normal group; ${ }^{\#} \mathrm{p}<0.05,{ }^{\# \#} \mathrm{p}<0.01$ compared with the model group; ${ }^{\&} \mathrm{p}<0.05,{ }^{\& \&} \mathrm{p}<0.01$ compared with low dose group; ${ }^{\circledR} \mathrm{p}<0.05$, compared with Flunarizine group

Effects of alcoholic extracts of Chuanxiong Rhizoma-Cyperi Rhizoma combination on neurotransmitters and inflammatory factors in migraine rats

The migraine model determined a significant decrease in the level of 5-HT and $\beta$-EP and a significant increase in the level of CGRP, IL-1 $\beta$, and TNF- $\alpha$ both in serum and brain tissue compared with the normal group $(\mathrm{p}<0.05)$. The Flunarizine and
Chuanxiong Rhizoma-Cyperi Rhizoma (CR-CR) combination treatment significantly increased the level of 5-HT and $\beta$-EP, and significantly decreased the level of CGRP, IL-1 $\beta$ and TNF- $\alpha$ both in serum and brain tissue compared with the model group. The effect of CR-CR combination was dosedependent and the increase of 5-HT levels was superior to Flunarizine for the highest used concentration (Figure 1).
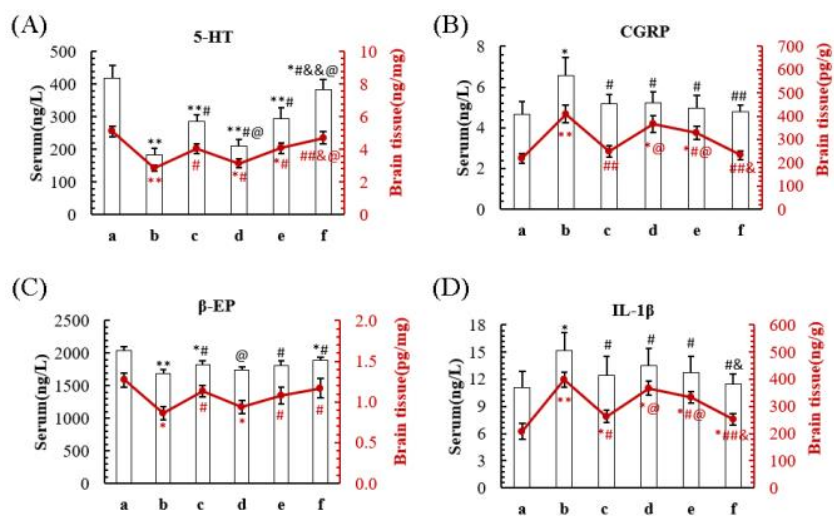

(D)

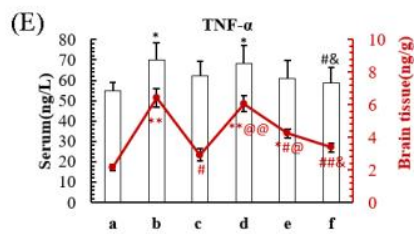

Figure 1.

Effect of alcoholic extracts from Chuanxiong Rhizoma-Cyperi Rhizoma on neurotransmitters and inflammatory factors. a: The normal group; b: The model group; c: The Flunarizine group; d: The low dose group; e: The medium-dose group; f: The high-dose group. Compared with the normal group, $* p<0.05, * * p<0.01$;

Compared with the model group, ${ }^{\#} \mathrm{p}<0.05,{ }^{\# \#} \mathrm{p}<0.01$; Compared with the drug low-dose group, ${ }^{\&} \mathrm{p}<0.05,{ }^{\& \&} \mathrm{p}$ $<0.01$; Compared with Flunarizine group, ${ }^{\circledR} \mathrm{p}<0.05, \stackrel{@}{{ }^{@} \mathrm{p}<0.01}$ 
FARMACIA, 2021, Vol. 69, 4

Effects of alcoholic extracts from Chuanxiong Rhizoma-Cyperi Rhizoma on vasoactive substances in migraine rats

The migraine modelling determined a significant decrease of the ET level and a significant increase of NO level, NOS activity and NO/ET ratio in the serum compared with the normal $(\mathrm{p}<0.05)$. The Flunarizine and Chuanxiong Rhizoma-Cyperi

(A)
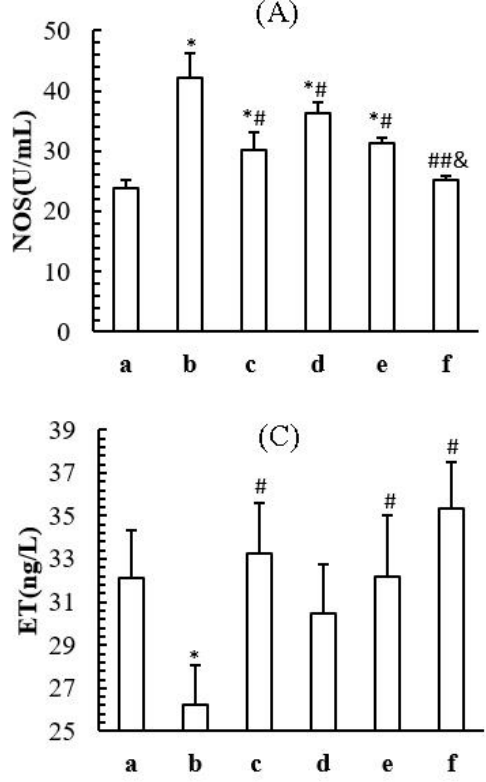

Rhizoma combination treatment significantly increased the level of ET levels, and significantly decreased the level of NO level, NOS activity and NO/ET ratio in the serum. The effect of the assessed rhizome combination was dose-dependent and there was no significant difference between the CR-CR combination group and Flunarizine group $(\mathrm{p}>0.05)$ (Figure 2).
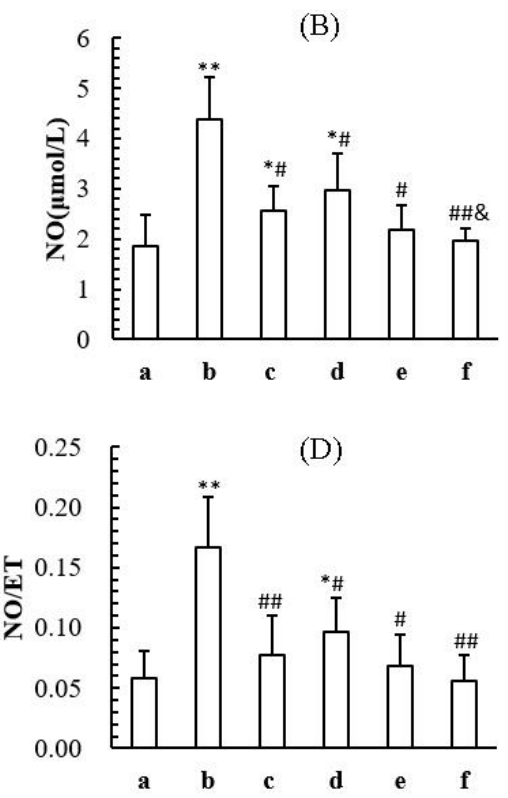

Figure 2.

Vasoactive substances in brain stem of migraine rats. a: The normal group; b: The model group; c: The Flunarizine group; d: The low dose group; e: The medium-dose group; f: The high-dose group. *p $<0.05, * * p<0.01$ compared with the normal group; ${ }^{\#} \mathrm{p}<0.05,{ }^{\#} \mathrm{p}<0.01$ compared with the model group; ${ }^{\&} \mathrm{p}<0.05$ compared with the drug low-dose group

Chuanxiong Rhizoma contains sodium ferulate that improves cerebral haemodynamics in patients with migraine [9] and senkyunolide I that can modulate the cortical diffusion inhibitory potential and the level of NO and CGRP in migraine rats [10]. Cyperi Rhizoma contains volatile oils, alkaloids, flavonoids and other ingredients. Among them, $\alpha$ Cyperone is the main component of Cyperi Rhizoma with analgesic effects [11] that inhibit the production of $\mathrm{NO}, \mathrm{O}_{2}$ and the expression of iNOS through the NF- $\kappa \mathrm{B}$ signalling pathway [12] and increase serotonin (5-HT) and dopamine (DA) generation [13].

Flunarizine, is a cerebral calcium antagonist used in the prophylaxis of migraine attacks but with a lot of side effects as somnolence, weight gain, and rarely extrapyramidal motor effects and depression [14]. In this study, the pre-treatment with Flunarizine for 7 days was used as a positive group of antimigraine effects.

In our study, migraine modelling using nitroglycerin injection determined the appearance of red ears in the following 4 minutes after nitroglycerin administration, followed by irritability, increased activity, increased scratching of the front and hind limbs. The rats from the groups pre-treated with traditional Chinese medicine combination and Flunarizine showed this behaviour with less intensity proving their ability to decrease migraine time. The pre-treatment with Chuanxiong Rhizoma-Cyperi Rhizoma combination was superior to the Flunarizine effect in a dose-dependent manner. Migraine is a common paroxysmal neurovascular disease with complex pathogenesis and complicated pathophysiological processes. The core of the pathological mechanism is neurogenic inflammation [15, 16]. A variety of neuropeptides and inflammatory factors are involved in the process of neurogenic inflammation. The most closely related is CGRP which stimulates platelet activation, mast cell degranulation, and production of inflammatory factors such as IL- $1 \beta$, TNF- $\alpha$ that are implicated in the appearance of pain [17]. 5-HT is a mediating neurotransmitter for receptors and target cells, which produces biological effects that cause migraines. It is believed that $5-\mathrm{HT}$ is another 
important factor implicated in the onset of migraine. Currently, the treatment of migraines is associated with the modulation of 5-HT [18, 19]. In this study, we showed that the expression of IL- $1 \beta$ and TNF- $\alpha$ in the midbrain and plasma of migraine rats increased, and the expression of 5-HT decreased. These effects were counteracted by the pre-treatment with Chuanxiong Rhizoma-Cyperi Rhizoma combination in a dose-dependent manner, similar to the effects registered after the pre-treatment with Flunarizine.

In recent years, studies suggest that migraine is closely related to the disorders of the endogenous opioid system. $\beta$-EP is the main transmitter of the body's analgesic system and has a morphine-like analgesic effect [20]. The decrease in $\beta$-EP levels weakens the inhibition of locus coeruleus and determine the release of a variety of vasoactive substances, which leads to dysfunction of cerebral vasomotor function, promoting the migraine duration $[21,22]$. The results of this study showed that the level of $\beta$-EP in the brainstem of migraine rats from the model group was reduced. The treatment with Chuanxiong Rhizoma-Cyperi Rhizoma combination significantly increases the level of $\beta$-EP in treated migraine rats in a dosedependent manner, similar to the effects observed for the positive control group.

The rat migraine model was obtained by subcutaneous injections with nitroglycerin. The mechanism that underwent this model is that nitroglycerin determines the production of NO in the body, which has a strong effect of expanding cerebral blood vessels and can also induce trigeminal ganglion cells to synthesize and secrete CGRP [23]. CGRP can dilate blood vessels and cause experimental migraines [24]. ET is the strongest vasoconstrictor substance found so far, which balances with the release of NO to maintain the normal state of blood vessels. The change in the ratio of NO/ET can be used to study the effect of drugs on migraines [25]. In our study, we observed an increase in the level of CGRP, NO, ET, and NOS in the model group. The pre-treatment with the traditional Chinese medicine combination can alleviate these changes in varying degrees. We proved that Chuanxiong Rhizoma-Cyperi Rhizoma combination alleviates the migraine by regulating of increase of vasomotor factors such as CGRP, NOS, NO, ET. These effects are similar to those previously reported by Wu et al. [5].

\section{Conclusions}

In summary, the pre-treatment with Chuanxiong Rhizoma-Cyperi Rhizoma combination could shorten the time of migraine attack in rats, improve the migraine state, and promote cerebral blood circulation, whose mechanism might be related to the regulation of neurogenic inflammation, the release of neurotransmitters and vasoactive substances so that the brain vasomotion and central analgesia could be regulated, thereby effectively treating migraine. In conclusion, the alcoholic Chuanxiong Rhizoma-Cyperi Rhizoma extract could be a promising agent for migraine prophylaxis that should be further investigated in clinical studies.

\section{Conflict of interest}

The authors declare no conflict of interest.

\section{References}

1. Scher AI, Wang SJ, Katsarava Z, Buse DC, Fanning KM, Adams AM, Lipton RB, Epidemiology of migraine in men: Results from the Chronic Migraine Epidemiology and Outcomes (CaMEO) Study. Cephalalgia, 2019; 39(2): 296305.

2. Liu Z K, Ng C F, Shiu H T, A traditional Chinese formula composed of Chuanxiong Rhizoma and Gastrodiae Rhizoma (Da Chuanxiong Formula) suppresses inflammatory response in LPS -induced RAW 264.7 cells through inhibition of NF- $\kappa B$ pathway. J Ethnopharmacol., 2016; 196: 20-28.

3. Sim Y, Choi JG, Gu PS, Ryu B, Kim JH, Kang I, Jang DS, Oh MS, Identification of Neuroactive Constituents of the Ethyl Acetate Fraction from Cyperi Rhizoma Using Bioactivity-Guided Fractionation. Biomol Ther., 2016; 24(4): 438-445.

4. Yi T, Fang JY, Zhu L, Tang YN, Ji H, Zhang YZ, Yu JC, Zhang XJ, Yu ZL, Zhao ZZ, Chen HB, The variation in the major constituents of the dried rhizome of Ligusticum chuanxiong (Chuanxiong) after herbal processing. Chin Med., 2016; 11: 26: 18.

5. Wu S, Guo L, Qiu F, Gong M, Anti-Migraine Effect of the Herbal Combination of Chuanxiong Rhizoma and Cyperi Rhizoma and UPLC-MS/MS Method for the Simultaneous Quantification of the Active Constituents in Rat Serum and Cerebral Cortex. Molecules, 2019; 24(12): 2230: 1-28.

6. Gao JL, Chen G, He QY, Li J, Wang J, Analysis of Chinese patent medicine prescriptions for Qi stagnation and blood stasis syndrome. Zhongguo Zhong Yao Za Zhi, 2017; 42(1): 187-191 (available in Chinese).

7. Wei Y, Hu J, Li H, Liu J, Preparative isolation and purification of senkyunolide-I, senkyunolide-H and ferulic acid from Rhizoma Chuanxiong using counter-current chromatography. J Sep Sci., 2011; 34(23): 3426-3432.

8. Salehi B, Capanoglu E, Adrar N, Catalkaya G, Shaheen S, Jaffer M, Giri L, Suyal R, Jugran AK, Calina D, Docea AO, Kamiloglu S, Kregiel D, Antolak H, Pawlikowska E, Sen S, Acharya K, Selamoglu Z, Sharifi-Rad J, Martorell M, Rodrigues CF, Sharopov F, Martins N, Capasso R, Cucurbits Plants: A Key Emphasis to Its 
FARMACIA, 2021, Vol. 69, 4

Pharmacological Potential. Molecules 2019; 24(10): 1854: 1-23.

9. Zhang Y, Yang LJ, Wang XX, Ma XY, Yu J, Jia P, Yue Q, Yang PY, Zheng XH, Effect of rhizoma cyperi on pharmacokinetics of ferulic acid in ligusticum wallichii in normal and nitroglycerininduced migraine rats. Academic Journal of Second Military Medical University, 2014; 35(9): 10241028 (available in Chinese).

10. Wang YH, Liang S, Xu DS, Lin X, He CY, Feng Y, Hong YL, Effect and mechanism of senkyunolide I as an anti-migraine compound from Ligusticum chuanxiong. J Pharm Pharmacol., 2011; 63(2): 261-266.

11. Hong YL, Feng Y, Xu DS, Liu HJ. [Study on extraction and purification of active parts from Da Chuan Xiong Fang for treatment of migraine]. Zhong Yao Cai, 2007; 30(6):721-723 (available in Chinese).

12. Huang B, He D, Chen G, Ran X, Guo W, Kan X , Wang W, Liu D, Fu S, Liu J, $\alpha$-Cyperone inhibits LPS-induced inflammation in BV-2 cells through activation of Akt/Nrf2/HO-1 and suppression of the NF-кB pathway. Food Funct., 2018; 9: 2735-2743.

13. Choi JG, Kang SY, Kim JM, Roh DH, Yoon SY, Park JB, Lee JH, Kim HW, Antinociceptive Effect of Cyperi rhizoma and Corydalis tuber Extracts on Neuropathic Pain in Rats. Korean $J$ Physiol Pharmacol., 2012; 16(6): 387-392.

14. Schmidt R, Oestreich W, Flunarizine in migraine prophylaxis: the clinical experience. $J$ Cardiovasc Pharmacol., 1991;18 (Suppl 8):S21-S26.

15. Kilinc E, Tore F, Dagistan Y, Guler B, Thymoquinone Inhibits Neurogenic Inflammation Underlying Migraine Through Modulation of Calcitonin Gene-Related Peptide Release and Stabilization of Meningeal Mast Cells in Glyceryltrinitrate-Induced Migraine Model in Rats. Inflammation, 2020; 43(1): 264-273.

16. Bulboacă AE, Porfire A, Barbălată C, Bolboacă SD, Nicula C, Boarescu PM, Stănescu I, Dogaru G, The effect of liposomal epigallocatechin gallate and metoclopramide hydrochloride co-administration on experimental migraine. Farmacia, 2019; 67(5): 905-911.

17. Wang MM, Yu XH, Geng W, Cui HF, Wang CC, Han J, Yang DH, Effect of Manual Acupuncture
Preconditioning on Behavior and Contents of Serum CGRP, SP, IL- $1 \beta$ and TNF- $\alpha$ Levels in Migraine Rats. Zhen Ci Yan Jiu, 2018; 43(6): 375379 (available in Chinese).

18. Nagata E, Shibata M, Hamada J, Shimizu T, Katoh Y, Gotoh K, Suzuki N, Plasma 5hydroxytryptamine (5-HT) in migraine during an attack-free period. Headache, 2006; 46(4): 592596.

19. Piątkowska-Chmiel I, Popiołek Ł, GawrońskaGrzywacz M, Natorska-Chomicka D, Izdebska M, Herbet M, Dudka J, Poleszak E, Wujec M, The analgesic effect of 1,3-thiazolidin-4-one derivatives as potential modulators of the serotoninergic system. Farmacia, 2019; 67(2): 258-266.

20. Rhodin A, Grönbladh A, Ginya H, Nilsson KW, Rosenblad A, Zhou Q, Enlund M, Hallberg M, Gordh T, Nyberg F, Combined analysis of circulating $\beta$-endorphin with gene polymorphisms in OPRM1, CACNAD2 and ABCB1 reveals correlation with pain, opioid sensitivity and opioidrelated side effects. Mol Brain, 2013; 6(1): 6-8.

21. Misra UK, Kalita J, Tripathi GM, Bhoi SK, Is $\beta$ endorphin related to migraine headache and its relief? Cephalalgia, 2013; 33(5): 316-322.

22. Misra UK, Kalita J, Tripathi G, Bhoi SK, Role of $\beta$ endorphin in pain relief following high rate repetitive transcranial magnetic stimulation in migraine. Brain Stimul., 2017; 10(3): 618-623.

23. Ramachandran $\mathrm{R}$, Bhatt $\mathrm{DK}$, Ploug KB, HaySchmidt A, Jansen-Olesen I, Gupta S, Olesen J, Nitric oxide synthase, Calcitonin Gene-Related Peptide and inflammatory mechanisms are involved in GTN induced neuronal activation. Cephalalgia, 2013; 14(Suppl 1): P217-P217.

24. Kilinc E, Guerrero-Toro C, Zakharov A, Vitale C, Gubert-Olive M, Koroleva K, Timonina A, Luz LL, Shelukhina I, Giniatullina R, Tore F, Safronov BV, Giniatullin R, Serotonergic mechanisms of trigeminal meningeal nociception: Implications for migraine pain. Neuropharmacology, 2017; 116: 160-173.

25. Sun J, Li H, Sun J, Liu H, Chen J, Wang C, Chemical Composition and Antimigraine Activity of Essential Oil of Angelicae dahuricae Radix. $J$ Med Food, 2017; 20(8): 797-803. 